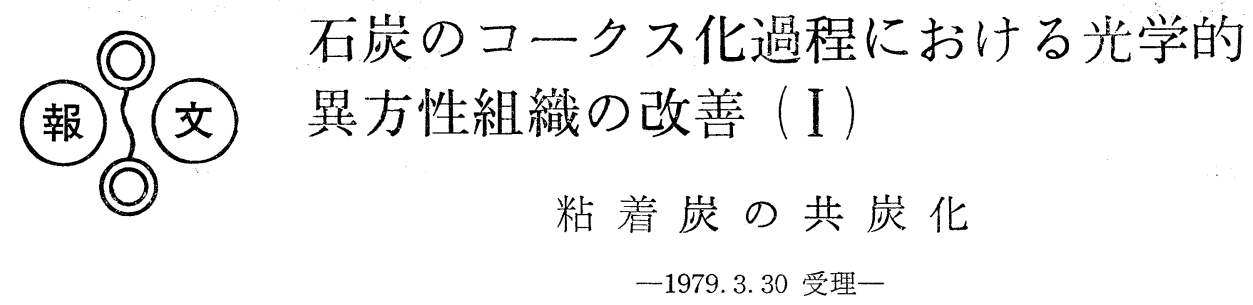

\author{
九州大学生産科学研究所* 持田熏, 森 山 清 治, \\ 松岡秀一，前田 恵子， \\ 藤 津博，竹下 健次郎 \\ University of Newcastle upon Tyne** Harry Marsh
}

\section{1. 緒言}

大型高炉用コークスは高炉内での操業に耐える強度 を有することが必須である。この強度は物理的少よび 化学的な要因からなっているが，いずれにしてるコー クスの構造と密接に関連している。構造因子のうち偏 光顕微鏡によって観察されるコークスの光学的組織 は, 高炉内での二酸化炭素之の反応と密接比関連して いるとされている。この反応沙っって引き起こる多孔 質化は, 高炉内の機械的な粉化に対する抵抗力を減少 させる。この化学反応は石炭の不活性質に由来する組 織や溶融着不良の部分で打こりやすく ${ }^{1)}$, 等方性コ一 クスは一般に異方性コークス汇比較して二酸化炭素と の反応性が高いため, 粗粒状モザイク構造や流れ構造 などの異方性組織が，高炉内の熱間コークス強度に対 する重要な成分であると指摘されている2゙。一方，石 炭からのコークスの光学的組織構造は, 石炭化度に上 り大略決定され，強粘結炭が異方性組織の上く発達し たコークスを与光るのに対して，低炭化度炭からのコ

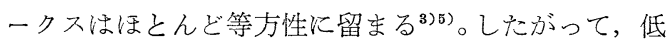
炭化度炭を高炉用コークス源として利用する際住， これらの石炭から異方性組織を誘導することが要求さ れょう。実用上の見地から，炭化時汇粘結剤を添加す る研究は広く試みられているが, 異方性組織の誘導に ついてはあまり注意が払われていない。真田らは，石 炭と重質油の混合炭化を試み, ある種の石炭に対して

* 九州大学生産科学研究所 福网市東区箱崎

** Northern Carbon Research Laboratories, School of Chemistry, University of Newcastle upon Tyne
異方性組織が誘導できることを報告し，㓴者の相溶作 用の見地から，石炭を膨潤化せしめるためには芳香族 棈造の発遟した重質油の使用を提案している6)。

一般に, 異方性組織を誘導するために怯, 適当な炭 化反応性と宸化中間体構造をもって，液相状態を経て 炭化が進行するように反応条件を設定する必要があ る。このような観点からすれば，低石炭化度炭からも， 炭化条件の設定によっては, 大きな異方性組織を展開 件せしめることが可能なはずである。本報では，炭化条 の調節，炭化触媒もしくは共炭化剂の添加炕よる粘着 炭の炭化反応制御を行ない, 生成コークスの異方性組 織の改善を検討した。粘着炭は主として等方性コーク スを与光るが，炭化時には溶融するので，上述の考察 から, 異方性の誘導は非溶融炭に比較して容易と推定 できる。なお，著者らは，各種石炭との共炭化におけ る各種添加剤の効果については別に報告している7)。

\section{2. 実}

2.1 試 料

石炭は, 粘着炭汇属する三池炭を使用した。兏分 9.0 \%，揮発分 $38.3 \%$, 固定炭素 $52.7 \%$, 元素分析値 C : 82.7, H: 5.9, N : 1.3, $\mathrm{S}: 0.8, \mathrm{O}: 9.3$, 喽化点 $353^{\circ} \mathrm{C}$, ビトリニット成分 $90 \%$ である。

使用した触媒 $\left(\mathrm{AlCl}_{3}\right)$, 炭化水素（ナフタレン，ア ントラセン，ピレン，アセナフチレン，デカサイクレ ン, ジヒドロアントラセン) は市販品（東京化成, 和 光，アルドリッチ)をそのまま用いた。また，重質油 は，エチレンタールピッチ (E T (興亜石油))，クレ ハピッチ (KP (呉羽化学工業)), A 200ピッチ(Ashland)，溶剤精製炭（S R C）の 4 種を用いた。E Tは 
Table 1 Properties of pitches

\begin{tabular}{|c|c|c|c|c|c|c|c|}
\hline $\begin{array}{l}\text { analyses } \\
\text { pitch } \\
\end{array}$ & $\begin{array}{c}\mathrm{C} \\
(\%)\end{array}$ & $\begin{array}{c}\mathrm{H} \\
(\%)\end{array}$ & $\mathrm{H} / \mathrm{C}$ & $\mathrm{H}_{\mathrm{a}}$ & $\begin{array}{c}\mathrm{H}-\mathrm{NN} \\
\mathrm{H}_{\alpha} \\
\end{array}$ & $\mathrm{H}_{0}$ & $\mathrm{H}_{r}$ \\
\hline $\mathrm{ET}^{1)}$ & 92.8 & 7.3 & 0.95 & 0.50 & 0.36 & 0.12 & 0.02 \\
\hline $\mathrm{KP}-\mathrm{BS}^{2)}$ & 94.0 & 5.1 & 0.65 & 0.76 & 0.17 & 0.06 & 0.01 \\
\hline A $200^{3)}$ & 91.6 & 4.9 & 0.64 & 0.58 & 0.28 & 0.11 & 0.03 \\
\hline SRC-BS ${ }^{4)}$ & 88.2 & 6.5 & 0.88 & 0.53 & 0.27 & 0.18 & 0.02 \\
\hline $\left.\mathrm{H}-\mathrm{Py}^{5}\right)$ & 92.5 & 5.8 & 0.75 & 0.64 & 0.25 & 0.10 & 0.01 \\
\hline$H-A 200^{6)}$ & 76.0 & 7.7 & 1.2 & 0.14 & 0.37 & 0.38 & 0.11 \\
\hline
\end{tabular}

1) ethylene tar pitch 2) Kureha pitch-benzene soluble

3) Ashland pitch 4) SRC-benzene soluble

5 ) hydrogenated pyrene 6) hydrogenated Ashland pitch

全てベンゼン可溶分（BS）であるが，K P，A200お よびS R CはBSをそれぞれ35\%，70\%，60\%含む。

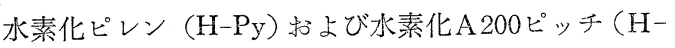
A200) は，ピレンあるいはA200を Li-エチレンジア ミン系による Birch 還元法 (前報) と同栐に, Reggel らの方法)によって得た。これらの元素分析值および NMR データをTable 1 K示す。

\section{2 崖 化}

三池宸 $(<150 \mu)$ 1 5g を石炭単味あるいは添加 剂 $(0.05 \sim 2.0$ 重量比) と混合し, パイレックス管 $(\phi 30$ $\times 300 \mathrm{~mm})$ に入れ，炭化管長の $1 / 3$ を電気炉外に保持し， 窒素気流下で熱処理した。昇温速度 $150 \sim 3,600^{\circ} \mathrm{C} / \mathrm{hr}$ で加熱し， $600^{\circ} \mathrm{C}$ で 2 時間保持した。得られた炭化物 は水洗後, アセトン, ベンゼンで洗浄, 乾燥し, コ一 クスを得た。

\section{3 偏光顕微鏡観察}

得られた炭化物はポリエステル系樹脂に埋め达み, 常法に従って研摩後, ライッ社製オルソルックス反射 偏光顕微鏡により，直交ニコル下で組織を観察した。 実験に使用した三池炭では珙方性組織と等方性組織と が共存しているので, 異方性単位の寸法とともに異方 性領域の広がりも観察した。コークスの構造単位の寸 法による分類は種々試みられているが4)10) 12), 本報で は活性質に由来する組織を次のように分類した。

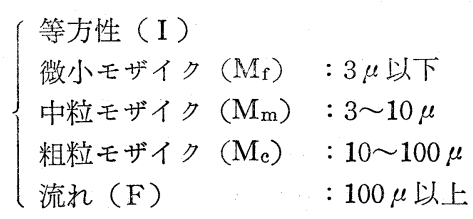

\section{$2.4 \mathrm{X}$ 線回析}

炭化物を小ルツボに入れ, さらに, それを, 石油系 コークスで充たした大きなルツボ中に 置き, $1,250^{\circ} \mathrm{C}$ で 1 時間仮焼後, アルゴン気流下 $2,500^{\circ} \mathrm{C} て ゙ ~ 30$ 分間黒
鉛化処理し, $\operatorname{CuK} \alpha$ 線を用い, 学振法に $\left.{ }^{13}\right)$ 準じて結晶 子の高さLc 打よび格子定数Co 求めた。

\section{3. 結果}

3.1 石炭単味の炭化

\section{1 .1 粒度の影響}

三池炭を粉砕して粒度の異なる 3 種の試料を作り， 石炭単味のコークス化を行ない, その光学的組織の大 きさを比較した。昇温速度は $1,200^{\circ} \mathrm{C} / \mathrm{hr}$ とした。 $3 \mathrm{~mm}$ 以上の塊状炭では, 等方性組織も混在するが, 大部分 微小モザイク組織である。150 $\mu$ 以下の粉炭では, 微小 モザイク組織もあるが，異方性単位以塊炭よりさらに 小さく，大部分は等方性であった。なお，粉炭を 300 $\mathrm{kg} / \mathrm{cm}^{2}$ の圧力で成型しペレット状の塊炭として岸化 しても, 異方性組織の展開の程度は大差なかった。

\section{1 .2 昇温速度の効果}

昇温速度を $150^{\circ} \mathrm{C}$ から $3,600^{\circ} \mathrm{C} / \mathrm{hr}$ に変化さ地, 三池 粉炭についてその効果を調べた。 $150^{\circ} \mathrm{C} / \mathrm{hr}$ で绀全面等 方性組織であったが, $600^{\circ} \mathrm{C} / \mathrm{hr}, 1,200^{\circ} \mathrm{C} / \mathrm{hr}$ では部分 的ではあるが微小モザイク組織がみられた。しかし， $3,600^{\circ} \mathrm{C} / \mathrm{hr}$ では $1,200^{\circ} \mathrm{C} / \mathrm{hr}$ の場合よりも幾分寸法の 小さい微小モザイク組織であった。石炭のコークス化 においても, ピッチの場合之同様, 昇温速度の上昇に より配向性が幾分改善されたが, ある種の強粘結炭で みられるような流れ組織 ${ }^{12) 14}$ には至らなかった。

\section{2 石崖の接触炭化}

著者らは, ピッチや芳香族崖化水素の炭化において, 塩化アルミニウムの共存が生成コークスの収率や配向

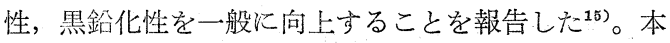
報では, 三池粘着炭 (粉炭) の炭化に打いて塩化アル ミニウムの添加効果学温速度の効果と併せて検討 し，結果そFig. 1 とTable 2 にまとめた。いずれの昇 温速度の場合にも, 塩化アルミニウム量の増加によっ て, 異方性組織の領域が増し, 触媒量が 0.5 重量比以 

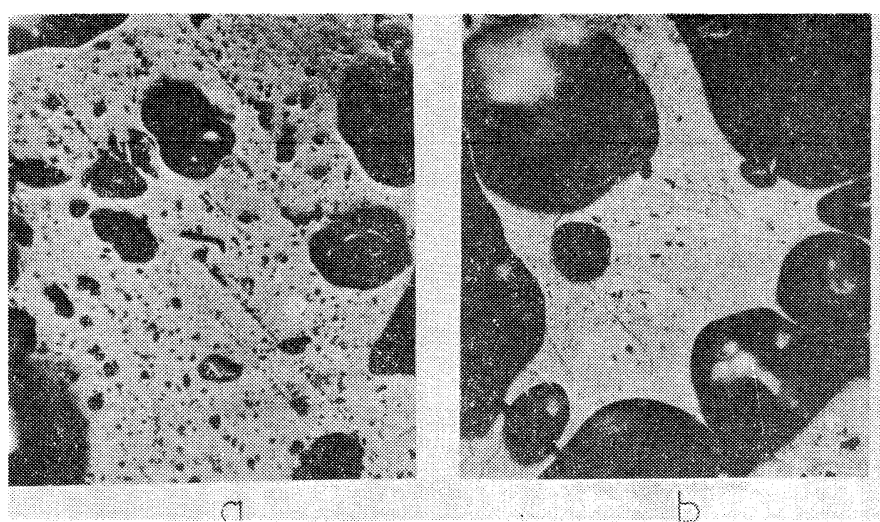

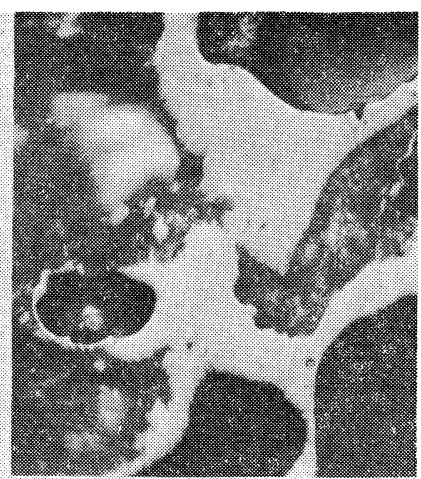

(x):

Fig. 1 Effect of $\mathrm{AlCl}_{3}$ amount on carbonization of Miike coal (x 140)

heat-treatment condition: $1200^{\circ} \mathrm{C} / \mathrm{hr}, 600^{\circ} \mathrm{C}-2 \mathrm{hr}$

$\mathrm{AlCl}_{3}$ amount (wt ratio): (a) 0 , (b) 0.5 , (c) 2.0

Table 2 Effect of catalyst on carbonization of Miike coal

\begin{tabular}{cllllll}
\hline $\begin{array}{c}\mathrm{AlCl}_{3} \begin{array}{l}\text { amount } \\
\text { (wt. ratio) }\end{array} \\
\text { heating rate } \\
\left({ }^{\circ} \mathrm{C} / \mathrm{hr}\right)\end{array}$ & 0 & 0.05 & 0.2 & 0.5 & 1.0 & 2.0 \\
\hline 150 & $\mathrm{I}$ & $\mathrm{I}$ & & $\mathrm{I}, \mathrm{Mf}$ & & \\
600 & $\mathrm{I}(\mathrm{Mf})$ & $\mathrm{I}(\mathrm{Mf})$ & $\mathrm{I}(\mathrm{Mf})$ & $\mathrm{I}, \mathrm{Mf}$ & & \\
1,200 & $\mathrm{I}(\mathrm{Mf})$ & & $\mathrm{I}(\mathrm{Mf})$ & $\mathrm{Mf}(\mathrm{I})$ & $\mathrm{Mf}(\mathrm{I})$ & $\mathrm{Mf}$ \\
3,600 & $\mathrm{I}$ & & $\mathrm{I}(\mathrm{Mf})$ & $\mathrm{I}, \mathrm{Mf}$ & & \\
\hline
\end{tabular}

Figures in parenthese refer to the small portion of the structure.

上になると，微小モザイク組織が広い領域に認められ るようになった。特に, 昇温速度 $1,200^{\circ} \mathrm{C} / \mathrm{hr}$ の場合は Fig. 1 亿示すように, 改善効果は顕著で, 触媒無添加 のときには上に述べたように三池粉炭から生成するユ 一クスは主として等方性組織であったのに, 触媒 0.5 モル比添加により一部等方性組織も残るが 8 割以上の 領域が微小モザイク組織を示した。さらに触媒量を 2 モル比に増加すると，等方性組織（不活性質等方性を 除く) は消失し, 全面微小モザイク組織となった。触 媒添加に上り展開するモザイク粒の大きさは触媒量の 増加によって影響されず，いずれの場合も数ミクロン 程度にとどまった。

\section{3 三池炭々芳香旅炭化水素との混合炭化}

著者らは，さきに，溶剤精製炭（S R C）のベンゼ ン不溶分 (B I ) を種々のピッチのベンゼン可溶分 （B S ）と共炭化すると，B S と B I 間の成分の相性 の違いにより、コークス組織が異なることを報告し

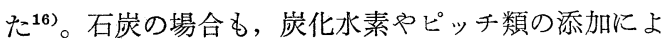
って, 溶融状態が修飾されて生成コークスの組織の変
化が期待される。三池粉炭について, 種々の炭化水素 との混合炭化によって生成したコークスの組織を Fig. 2,3 と Table 3 示す。ナフタレン, アントラセン, ピレンは単独では炭化しないが ${ }^{17) 18)}$, 昇温速度 1,200 ${ }^{\circ} \mathrm{C} / \mathrm{hr}$ で三池炭と共炭化すると，大部分の領域は等方 性であるが部分的に微小モザイク組織が出現した。特 にピレンでは，0.3 重量比添加でも微小モザイクが一 部現われ，他二者に比較して効果が大きい。しかし， この場合, コークス収率は非常に低いので, 炭化水素 は結果的には炭化することなく，ほとんど全て逸散し たと思われる。ここで用いた非還流の高速昇温の場合 には，炭化水素の見掛け沸点が高めになり溶融域が石 炭の軟化溶融域と幾分重盢し，炭化条件に影響をるつ ことは可能であろう。特に高沸点のピレンでは, 低軟 化点を有する三池炭と溶融域がかなり重冨し，その影 響が大きいものと考えられる。これはピレンの石炭液 化能と関連している ${ }^{19)}$ 。

ナフテン水素を保有する化合物は, 単独では炭化し ない点では上述の芳香族炭化水素と共通しているが， 

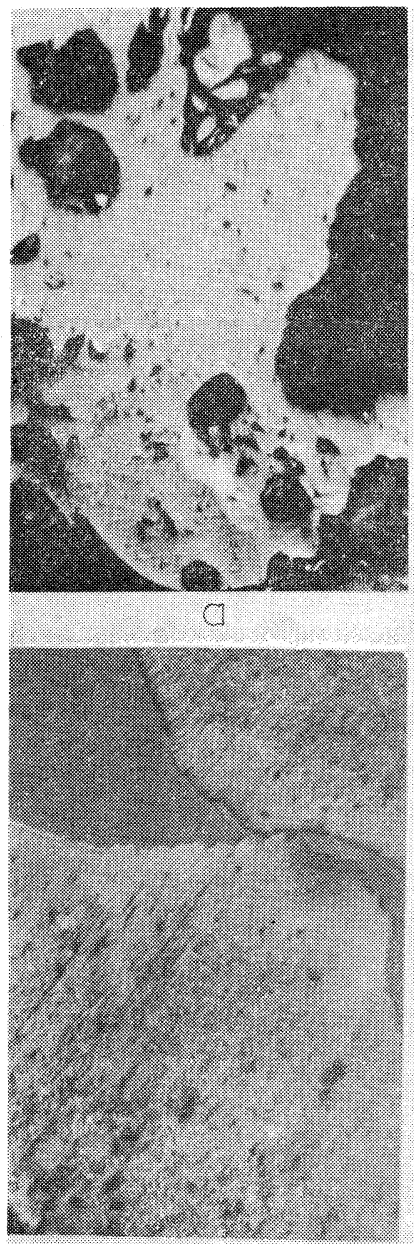

,

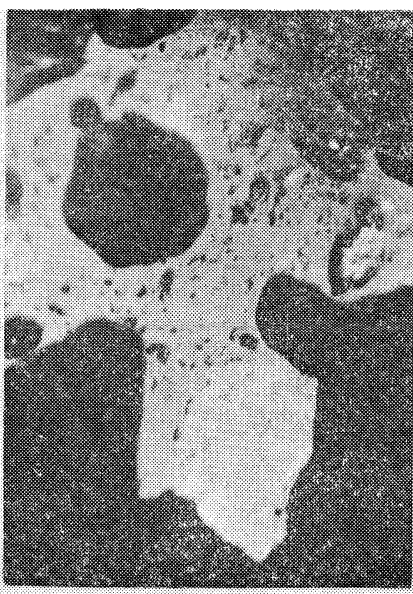

b

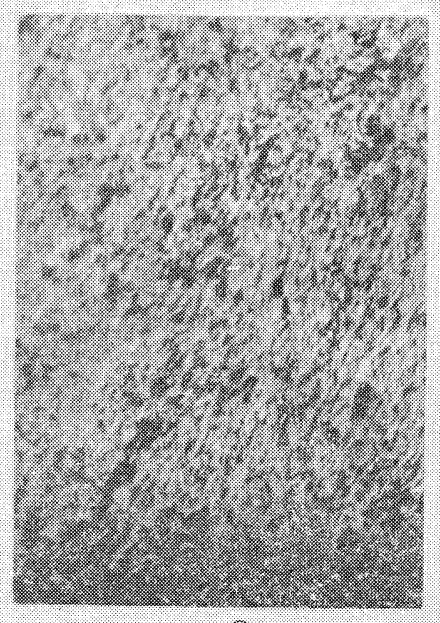

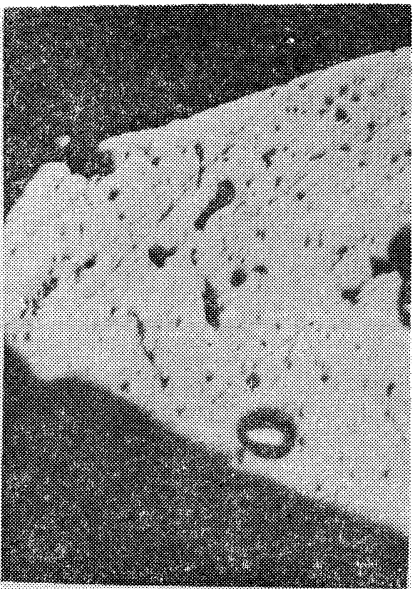

(.)

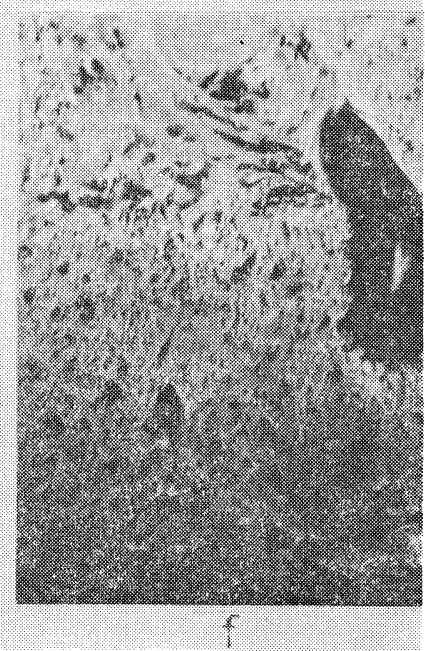

Fig. 2 Co-carbonization of Milke coal with aromatic hydrocarbons ( 140$)$ heat-treatment condition : (a)-(e) $1200^{\circ} \mathrm{C} / \mathrm{hr}$, (f) $150^{\circ} \mathrm{C} / \mathrm{hr}, 600^{\circ} \mathrm{C}-2 \mathrm{hr}$ hydrocarbon and mixing ratio (wt ratio) : (a) naphthalene 1 , (b) anthracene 1 , (c) pyrene 1 , (d) acenaphthylene 1, (e) acenaphthylene 2, (f) decacyclene 1.

その添加効果はずっと大きい。三池炭をハイドロピレ ンと昇温速度 $150^{\circ} \mathrm{C} / \mathrm{hr}$ で共炭化すると, 0.5 重量比添 加においてもコークスの大部分の領域が微小モザイク 組織となり，1.0 重量比では生成コークス全面が異方 性化し, さらに 2.0 重量比添加では異方性単位が大き くなり，粗粒モザイク組織へ変化した。このときのコ ークス取率から，ハイドロピレンはほとんど変化して いないことになる。ジヒドロアントラセン 添加（1.0 重量比）によっても，Fig. 3 に示すようにコークス全 面が異方性化した。

アセナフチレンおよびデカサイクレンは単独で炭化 し，異方性流れ構造を与える炭化水素であるが，石炭
との反応性も高い7)。三池炭との共炭化では，Fig. 2 に示すように昇温速度 $150^{\circ} \mathrm{C} / \mathrm{hr}$ で微小モザイク組織 が広い範囲にわたって出現した。特にデカサイクレン では, 0.3 重量比添加ですでにコークス全面が異方性 組織となり，1.0 重量比添加では粗粒モザイク組織も 出現した。アセナフチレンの系では, 昇温速度 1,200 ${ }^{\circ} \mathrm{C} / \mathrm{hr}$ で異方性単位がさらに大きくなり, 2.0 重量比 添加でコークス全面の光学組織は中粒モザイクとして 分類されよう。

\section{4 接触混合炭化}

3.3 で述べたように, アントラセン, ピレンの添加 は三池炭コークスの組織にわずかな影響しか与えなか 

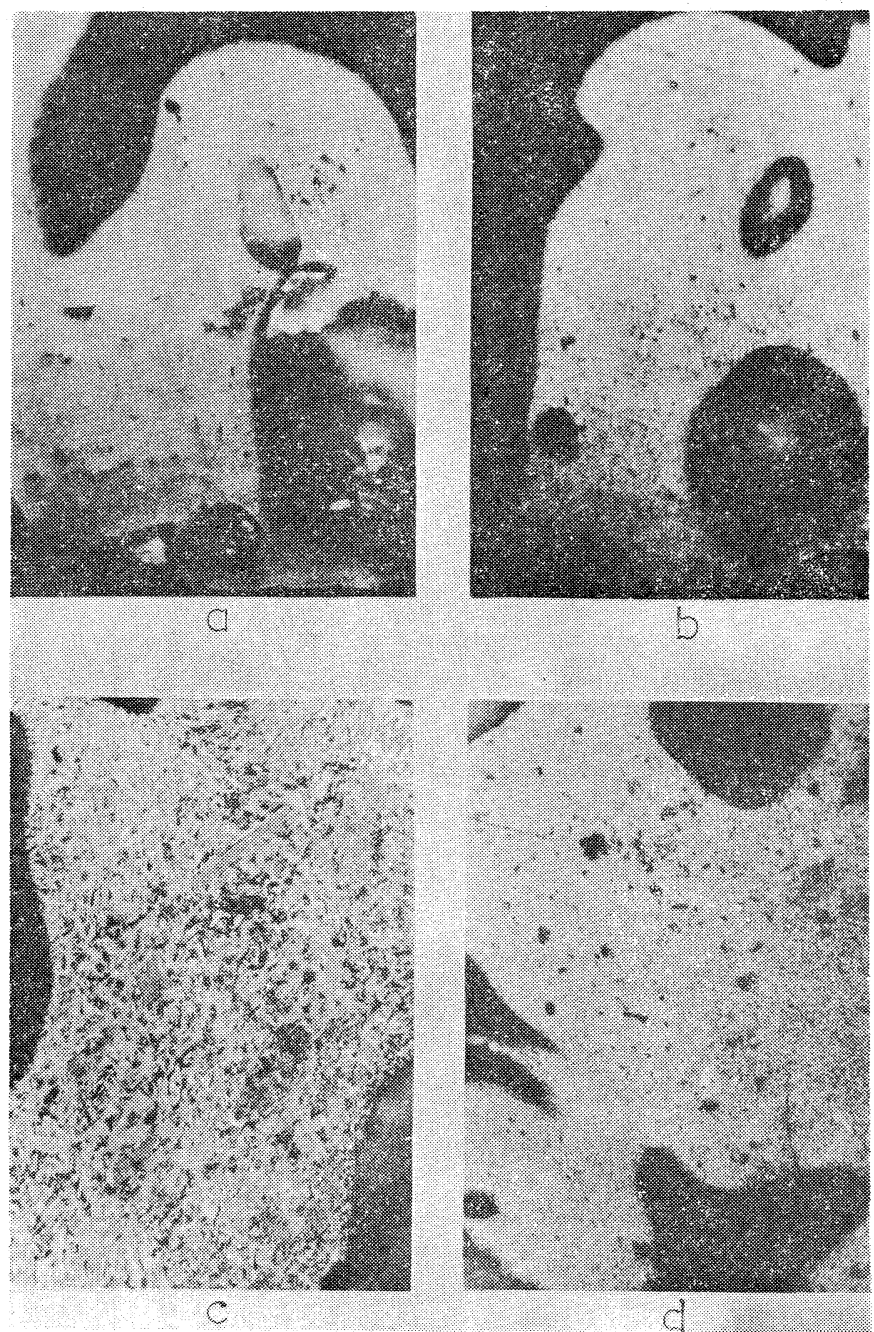

Fig. 3 Co-carbonization of Mike coal with hydrogenated pyrene or anthracene. (x 140) heat-treatment condition : $150^{\circ} \mathrm{C} / \mathrm{hr}, 600^{\circ} \mathrm{C}-2 \mathrm{hr}$

hydrocarbon and mixing ratio (wt ratio) : hydrogenated pyrene (a) 0.5 , (b) 1, (c) 2 , dihydroanthracene (d) 1

Table 3 Cocarbonization of Mike coal with aramatic hydrocarbons

\begin{tabular}{|c|c|c|c|c|c|c|}
\hline \multirow[t]{2}{*}{ hydrocarbons } & \multirow{2}{*}{$\begin{array}{l}\text { heating rate } \\
\left({ }^{\circ} \mathrm{C} / \mathrm{hr}\right)\end{array}$} & \multicolumn{5}{|c|}{ amount of hydrocarbon (wt. ratio) } \\
\hline & & 0.1 & 0.3 & 0.5 & 1.0 & 2.0 \\
\hline naphthalene & 1,200 & & & & $\mathrm{I}(\mathrm{Mf})$ & \\
\hline anthracene & $\begin{array}{r}150 \\
1,200\end{array}$ & $\mathrm{I}$ & $\begin{array}{l}\text { I } \\
\text { I }\end{array}$ & $\begin{array}{l}\mathrm{I} \\
\mathrm{I}(\mathrm{Mf})\end{array}$ & I & \\
\hline pyrene & 1,200 & $\mathrm{I}(\mathrm{Mf})$ & $\mathrm{I}(\mathrm{Mf}$ & $\mathrm{I}(\mathrm{Mt})$ & $\mathrm{I}(\mathrm{Mf})$ & $\mathrm{I}(\mathrm{Mf})$ \\
\hline dihydroanthracene & 150 & & & & Mf & \\
\hline H-Pyrene & 150 & & & $\operatorname{Mf}(\mathrm{I})$ & Mf & $\mathrm{Mc}$ \\
\hline acenaphthylene & $\begin{array}{r}150 \\
1,200\end{array}$ & & & $\begin{array}{l}I(M f) \\
I(M f)\end{array}$ & $\begin{array}{l}\operatorname{Mf}(I) \\
\operatorname{Mf}(I)\end{array}$ & $\begin{array}{l}\operatorname{Mf}(I) \\
\operatorname{Mm}(I)\end{array}$ \\
\hline decacyclene & 150 & & $\operatorname{Mf}(\mathrm{I})$ & $\operatorname{Mf}(\mathrm{I})$ & $\operatorname{Mf}, \operatorname{Mc}(I)$ & $\operatorname{Mf}(\mathrm{I})$ \\
\hline
\end{tabular}

Figures in parenthese refer to the sma!l portion of the structure. 

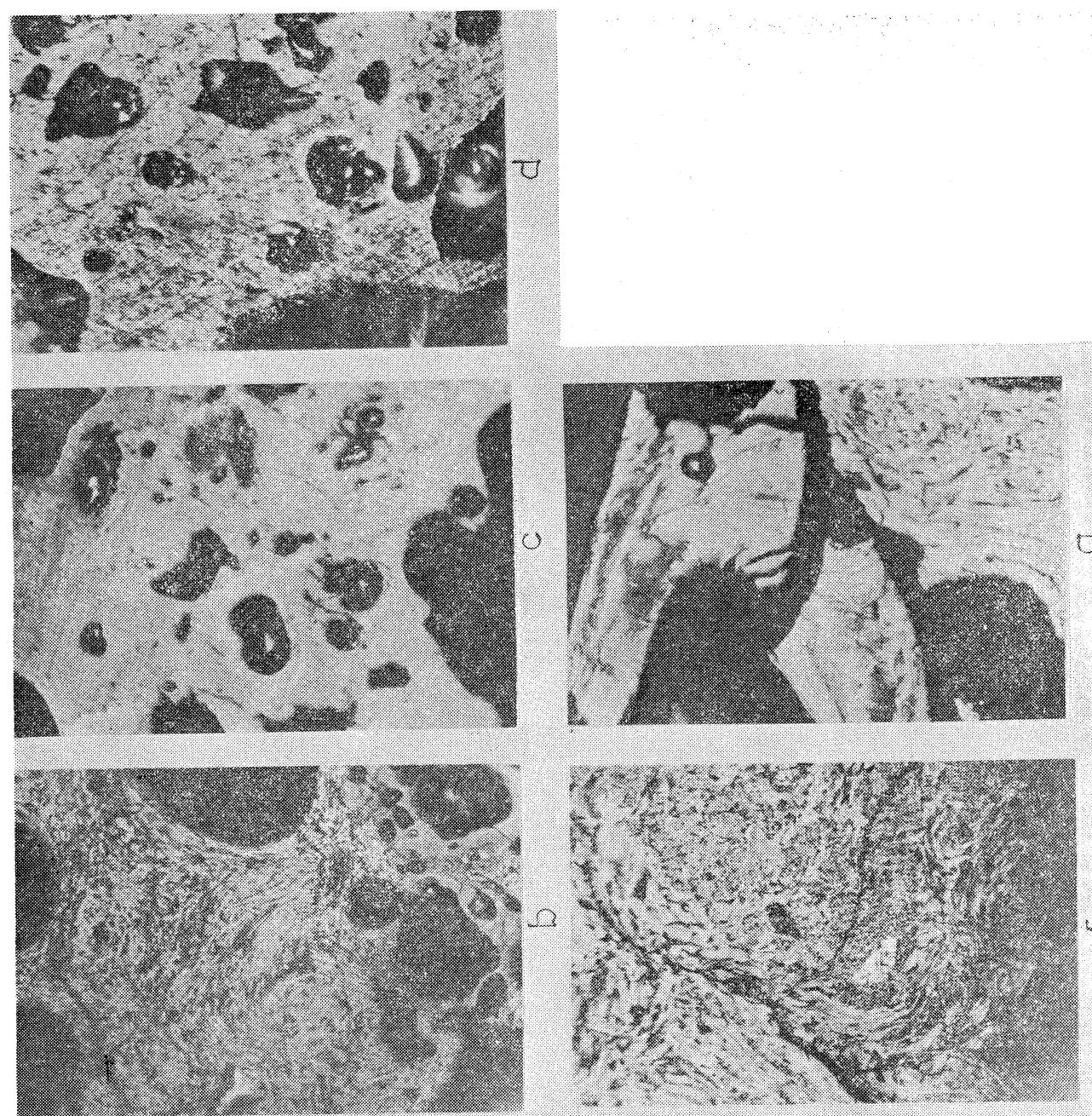
.

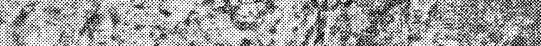

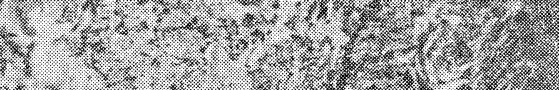

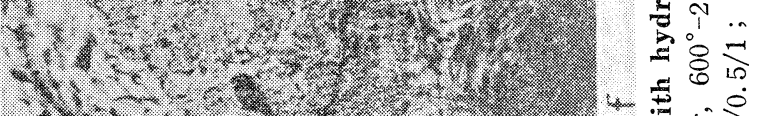

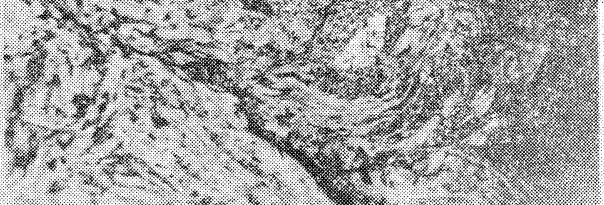
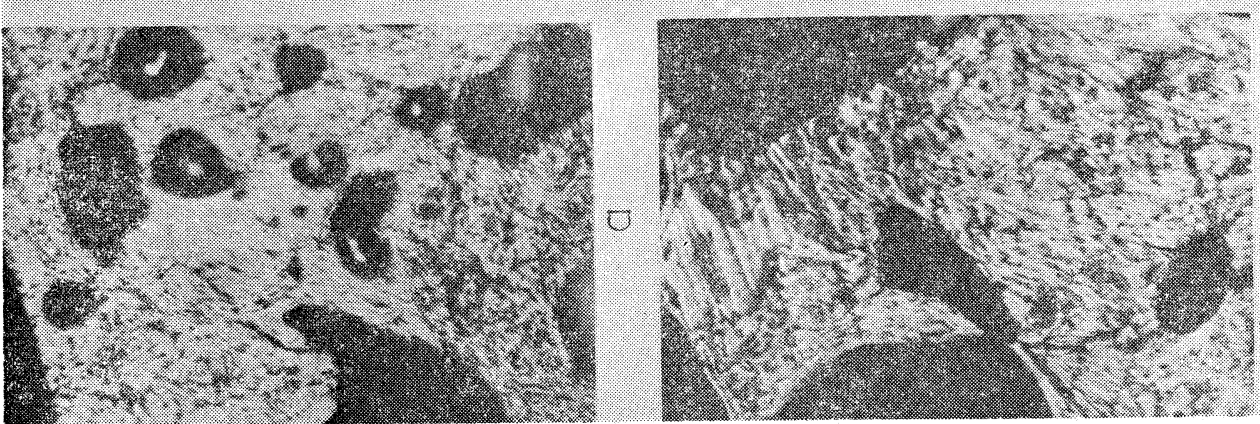

흉

ฐิ $N$ 8 เा ษ⿻ ธี 仓े

9. 궘 漠莒 荙要三 ๓ 范 . I

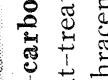
它 स $\dot{20}$

ったが，次に塩化アルミニウムを加えて，石炭との共 炭化による組織の改善を計った。石炭, 塩化アルミニ ウム, 炭化水素の 3 種混合系での炭化結果をFig. 4 と Table 4 亿示す。混合比 $1: 1: 1$ のとき広い領域で異 方性組織の展開が認められる。炭化水素がナフタレン の場合中粒モザイク，アントラセン，ピレンの場合流
れ組織が広く認められた。しかし，この場合でも等方性 組織が幾分残存している。塩化アルミニウムあるいは 炭化水素を減 少させた $1: 0.5: 1,1: 1: 0.5$ の混合 系では異方性単位が小さくなり, 主として微小モザイ ク組織となった。塩化アルミニウムを 2 倍量に増した $1: 2: 1$ および $1: 2: 2$ の系では, コークス中に等方 


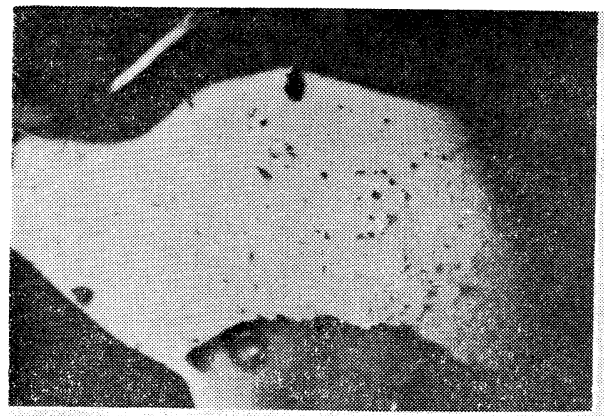

13

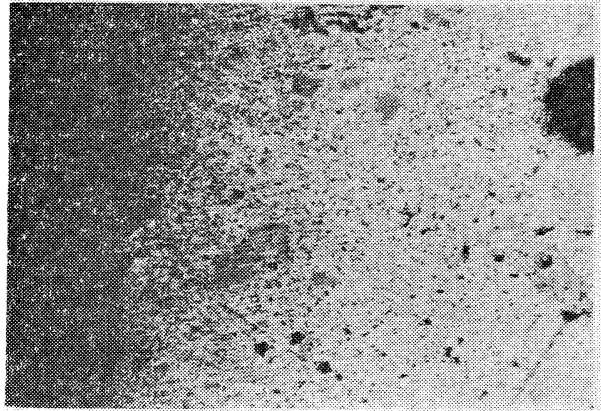

So

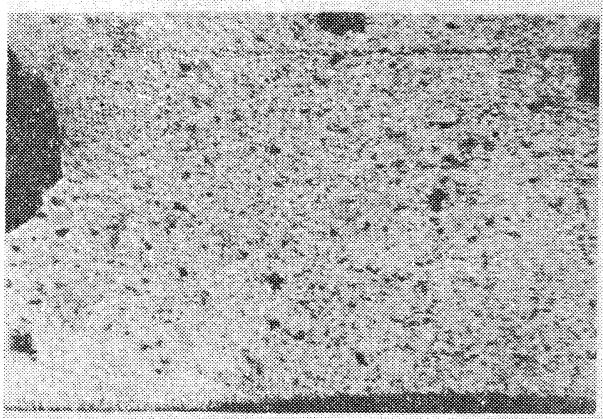

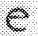

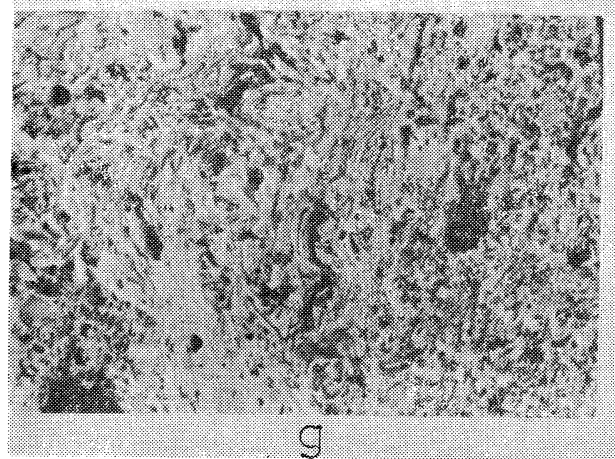

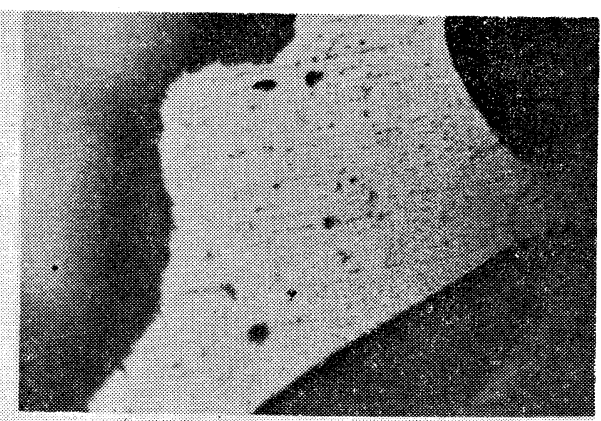

b

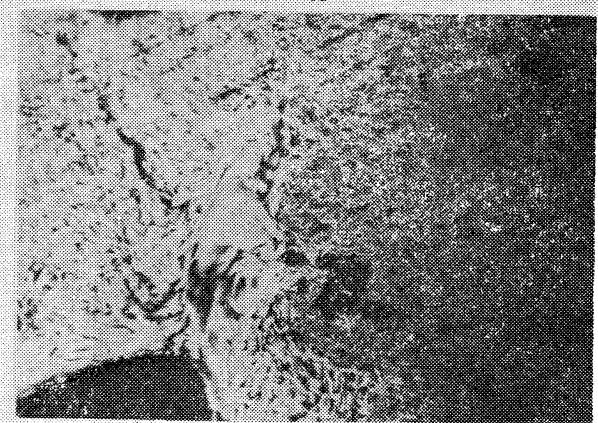

d

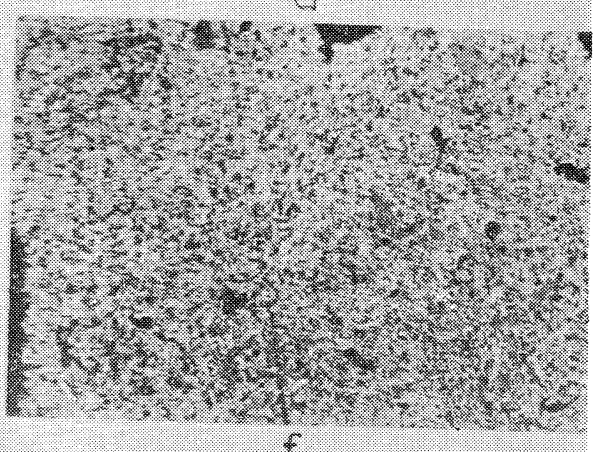

f

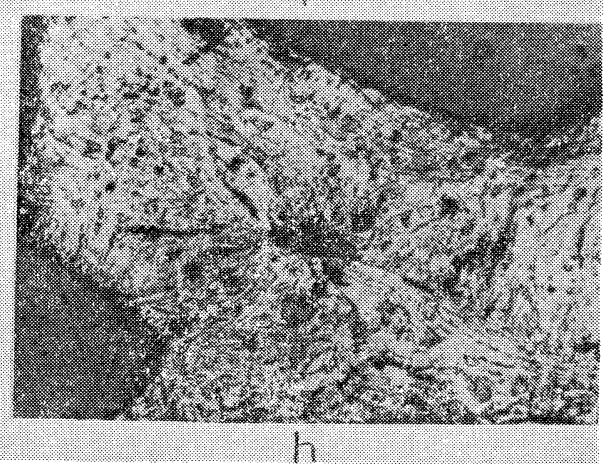

Fig. 5 Co-carbonizationof Miike coal with pitches (x 140)

heat-treatment condition : (a)-(f) $150^{\circ} \mathrm{C} / \mathrm{hr},(\mathrm{g})$ and (h) $600^{\circ} \mathrm{C} / \mathrm{hr}, 600^{\circ} \mathrm{C}-2 \mathrm{hr}$ pitch and mixing ratio (wt ratio): $\mathrm{ET}$ (a) 1 ; (b) $2, \mathrm{KP}-\mathrm{BS}$ (c) 1 ; (d) 2 , SRC-BS (e) 1 ; (f) $2, \mathrm{~A} 200$ (g) $2, \mathrm{H}-\mathrm{A} 200$ (h) 2 
Table 4 Cocarbonization of Miike coal with hydrocarbon in the presence of $\mathrm{AlCl}_{3}$

\begin{tabular}{|c|c|c|c|c|c|c|c|}
\hline \multirow[b]{2}{*}{ hydrocarbon } & \multirow{2}{*}{$\begin{array}{c}\text { heating rate } \\
\left({ }^{\circ} \mathrm{C} / \mathrm{hr}\right)\end{array}$} & \multicolumn{6}{|c|}{ coal : $\mathrm{AlCl}_{3}:$ hydrocarbon (wt. ratio) } \\
\hline & & $1: 0.5: 1$ & $1: 1: 0.5$ & $1: 1: 1$ & $1: 1: 2$ & $1: 2: 1$ & $1: 2: 2$ \\
\hline naphthalene & 1,200 & & & $\mathrm{Mm}, \mathrm{I}$ & & & \\
\hline anthracene & $\left\{\begin{array}{r}150 \\
1,200\end{array}\right.$ & $\begin{array}{l}\text { Mf, I } \\
\text { Mf, I }\end{array}$ & $\begin{array}{l}\text { Mf, I } \\
M f(I)\end{array}$ & $\operatorname{Mf}(\mathrm{I})$ & $\operatorname{Mm}(\mathrm{I})$ & & \\
\hline pyrene & 1,200 & $\mathrm{I}, \mathrm{Mf}$ & Mf, I & $\mathrm{F}, \mathrm{I}$ & Mc, I & $\mathrm{Mc}, \mathrm{Mf}$ & $\mathrm{F}, \mathrm{Mf}$ \\
\hline $\mathrm{H}$-pyrene & 150 & & & Mf, I & & & \\
\hline
\end{tabular}

Figures in the parenthese refer to the small portion of the structure.

性組織は認められず, コークス全面が異方性化し, 粗 粒モザイクや流れ組織が出現した。炭化水素として八 イドロピレンを用いた場合, 塩化アルミニウムを添加 すると微小モザイクと等方性組織が混在し, 3.3 で述 ベた塩化アルミニウム無添加の系よりも異方性組織の 発達の程度が低下した。

\section{5 三池炭と重質油との混合炭化}

三池炭と重質油との混合炭化の結果をFig. 5 亿示 す。ET，KP-BS，SRC-BS のいずれの重質油との混

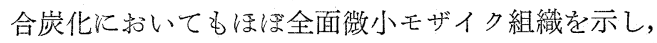
炭化水素十塩化アルミニウムの場合と比較すると, 同 一混合比では等方性領域は著しく減少している。重質 油の添加量を增すと, いずれのピッチの場合も異方性 単位が大きくないた。一方, A 200 ピッチとの共炭化で は, 2.0 重量比の添加でコークス全面が流れ組織を示 した。H-A200の添加によっても流孔組織を示した。 混合炭化に打いて出現する異方性単位の大きさは，同 一混合比の下で， $\mathrm{ET}<\mathrm{KP} \approx \mathrm{SRC}-\mathrm{BS}<\mathrm{A} 200$ の序列 となる。SRC-BS+塩化アルミニウムの混合添加で は, 等方性組織が増大し, 芳香旅炭化水素の場合 ${ }^{20)}$ と は逆の結果となっている。

\section{6 共炭化物の黑鉛化性}

前述のとおり, 溶融粘着性の三池炭について各種添 加剤との共炭化を行ない, 顕微鏡下での組織構造に新 たな变化を見い出し，両者の相互作用の発現が明らか になった。この相互作用はX線回析によっても示され ている。生成コークスの黒鉛化性はFig.6拈よびTable 5 に示してあるが, 三池炭単味では $2 \theta=26.2^{\circ}$ を中心 としてブロードなピークを描き，Lc100 A 程度の難黒 鉛化性炭素である。アセナフチレンおよびデカサイク レンは $2 \theta=26.5^{\circ}$ 付近に鋭いピークを示すが，石炭と この化合物との共炭化物は $2 \theta=26.4^{\circ}$ 付近の 1 本のピ 一クからなり, 黒鉛化性からみても, 石炭と炭化水素 が相互作用しながら均一系を実現し, 共炭化したこと

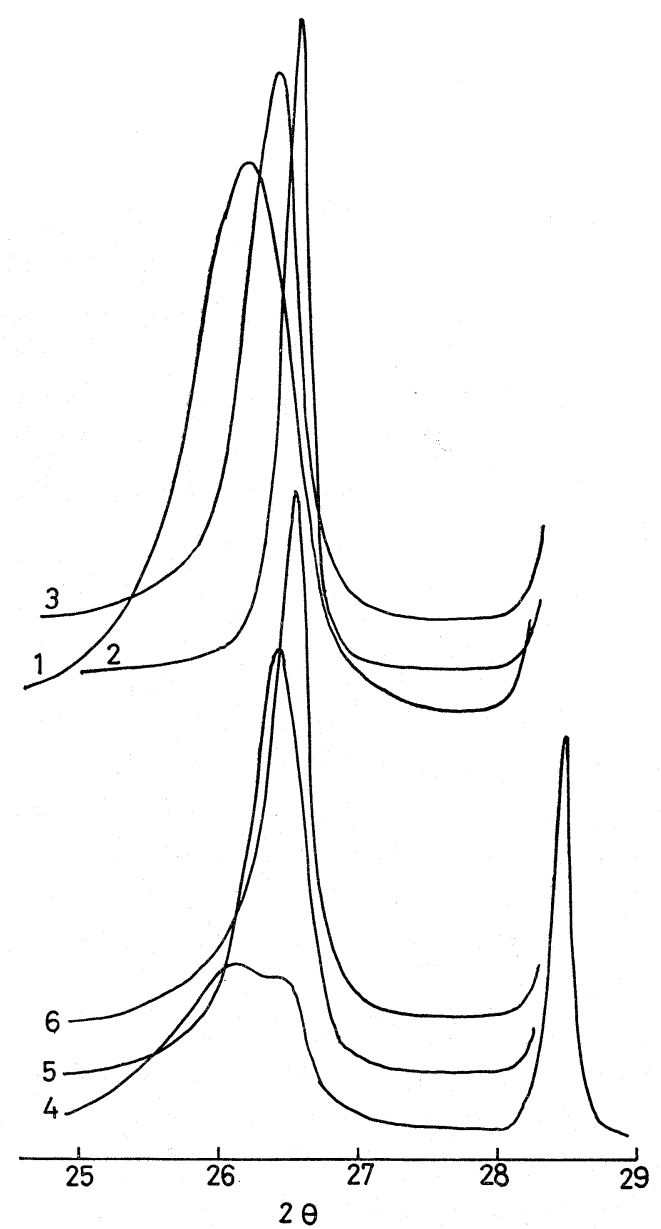

Fig. 6 X-ray diffraction protile of co-carbonization of Miike coal heat-treatment $\left(2500^{\circ} \mathrm{C}\right)$

(1) Miike coal, (2) acenaphthylene,

(3) Miike coal : acenaphthylene (1:1),

(4) Miike coal : pyrene (1:1),

(5) Miike coal : pyrene : $\mathrm{AlCl}_{3}(1: 1$ : 1), (6) Miike coal : $\mathrm{AlCl}_{\mathbf{3}}(1: 1)$ 
Table $5 \quad \mathrm{X}$-ray diffraction data of cokes from cocarbonization of Miike coal $\left(2,500^{\circ} \mathrm{C}\right)$

\begin{tabular}{|c|c|c|c|c|}
\hline sample & mixing ratio & $\begin{array}{c}\text { Co }(002) \\
(\AA)\end{array}$ & $\begin{array}{c}\text { Lc (002) } \\
(\AA)\end{array}$ & $\begin{array}{l}\text { optical } \\
\text { structure }\end{array}$ \\
\hline Mike & none & 6.811 & 120 & I \\
\hline acenaphthylene & none & 6.728 & 850 & $F$ \\
\hline decacyclene & none & 6.725 & $>1000$ & $\mathrm{Mc}$ \\
\hline Miike : $\mathrm{AlCl}_{3}$ & 1 & 6.725 & 520 & $\operatorname{Mf}$ \\
\hline Miike : py & 1 & 6.823 & $100^{*}$ & I \\
\hline Miike : py : $\mathrm{AiCl}_{3}$ & 1 & 6.762 & 320 & F, I \\
\hline Miike : Ace & $\begin{array}{l}1 \\
2\end{array}$ & $\begin{array}{l}6.749 \\
6.735\end{array}$ & $\begin{array}{l}260 \\
380\end{array}$ & $\begin{array}{l}M / 1 f \\
M f\end{array}$ \\
\hline Miike : Deca & $\left\{\begin{array}{l}1 \\
2\end{array}\right.$ & $\begin{array}{l}6.741 \\
6.730\end{array}$ & $\begin{array}{l}390 \\
460\end{array}$ & $\begin{array}{l}\text { Mf } \\
M f f\end{array}$ \\
\hline
\end{tabular}

を示している。

三池炭と塩化アルミニウムの系では，顕微鏡下では 微小モザイク組織であるにもかかわらず，Lcは $2520 \AA$ となり，易黑鈆化性炭素の生成を示している。一方， 三池炭に一部微小モザイクの出現したピレン添加系で は, 回折ピークは $2 \theta=26.2^{\circ}$ との二つに分裂しており ，黑鉛化性からみると，ピレンも石炭の一部と反応し て，生成コークスの易黒鉛化性に寄与しているといえ る。

\section{4. 若 整}

ピッチ類を含む有機化合物の炭化に就ける光学的璂 方性組織の出現機構は, Brooks-Taylor によって提唱 された多環芳香族化合物の縮合とその積層による液晶 メソフェーズ形成の段階的な過程である21) 26)。後者は 球晶の出現, 成長, 合体のステップからなり, 巽方性 組織の寸法ほこれらステップの相互関係により決ま る。これに対して, 石岸コークスに和ける異方性組縕 の出現はこのステップKよらないと考光る向きもあ

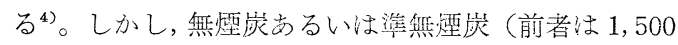
${ }^{\circ} \mathrm{C}$ 村近まで基本異方性（Basic Anisotropy）学維持す る。後者は $500^{\circ} \mathrm{C}$ 付近で基本異方性から葉状組織 (Domain に転移する。) を除いて，多くの石炭では異方性 組織の展開が一系列の炭化温度に対して, 段階的に発 達するものであるから，観察される初期異方性体が球 形をとっていないといえども，ピッチの炭化と同㥆の ステップからなると考学るべきであろう。実際, 初期 異方性体の形状は炭化系の条件によって強く影響され るものであり，ピッチ類から生じる初期異方性体にし ても種々の形態をとると報告されている21227) 30)ので, 石炭のみが真球の球晶を与えないわけではない。
上述の機權で光学的に等方性の石宸から光学的臀方 性体が出現し成長するためには, 亘大分子の再配列が 必要であり，これを実現する分子移動には，液相で岸 化が進行することが必須である。さらに，炭化過程に おいて心熱縮合曲進行し, 炭化系の粘度占上暑し, 最 終的に㴗固体に轱換されるので, 粘度の上暈が分子の 再配列積層と調和する必要がある。この上うな基本的 な議論ふら, 石崖の異方性出現機構を考察す秃ば, 石 炭は炭化時に溶融するか溶融しないかという蜆躊によ ってまぎ分類しなければならないと考光ることが適切 である。本実験で使用した三池炭は高流勤度炭として 考光らるものであるから, 炭化過程に就いて液相状

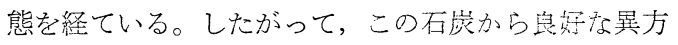
性構造坊展開しないのは, ピッチの場合に执いてすで に報告している3132) ように, 炭化速度, 炭化中間体, 共存炭化物等の因子が適切でないためである。本研究 では，これらの因子を暑温速度，触媒，共孷化によっ て制卸を諮みたと言換えることができよう。

高昇温速度の異方性展開に対方方好影響は Parrick ら4)によってすでに報告されている。本実験でも一般 にその傾向が認められた。急速景温のため, 石狋揮発 分の一部が炭化時まで保持され，また主てるる孷化反応 の進行温度が高くなり，炭化マトリックスの粘度を低 く維持できるので, 再固化過程に際して異方性出現に 有利となったのであろう。

塩化アルミニウム触媒は芳香旅炭化水榇の樎合反応 を促進する際にナフテン環構造を生成し，このような 炭化中間体が買方性展開には有利である ${ }^{31)}$ 。著者らは 芳香族炭化水素, エチレンタール, 高硫黄含有隇玨残 渣油から，同触媒が異方性流孔構造を生成せしめるこ 
とを報告している(15)20)。三池炭について，部分的では あるが異方性組織の展開が促進されていることは同一 の理由と考光られる。しかし，ここで異方性単位の寸 法は微小モザイクの範疇にとどまった。構成分子の分 子量の大きい SRC やギルソナイトピッチでは，塩化 アルミニウム触媒を用いると異方性組織は展開する が，寸法はもしろ縮小する15)。この場合，単独で炭化 しうる比䩙的分子量の大きい成分の炭化反忘性が，触 媒の添加により過大となり，大きな異方性単位の出現 が困難となると想定されたが，三池炭の場合当同様の 理由のために，微小モザイクにとどまったと考えられ る。

共崖化による炭化性の改善は添加物を添加するだけ で炉の変更も必要とせず，添加物自身もコークスに変 化すれば，触媒のように不純物となることもなく最も 好をしい方法とい方る。添加剤の役割は，炭化系に共 存することによって炭化時の種々の要因を制御するこ とにある。本研究に使用した添加剤は 1) 共炭化して コークスになるもの，2）炭化前に蒸発あるいは昇華 しそれ自身はほとんどコークスにならないが，崖化系 に其存する間に石炭と相互作用立る，ふたつの場合が 考光られる。本研究では，塩化アルミニウム共存下で のピレン等の芳香族炭化水素，岕るいは無触媒下での アセナフチレン, デカサイクレン, SRC, A 200 ピッ チが前者の例であり，ピレン，水素化ピレンが後者の 例である。いずれにしても，異方性組織の展開に適し た液相崖化条件をこれらの添加剤が作り得ることは， ピッチ成分のベンゼン可溶分および不溶分の共存化の 場合と共通しており，この機構についてはすでに報告 している ${ }^{16)}$ 。ナフテン環構造姿もつ添加剤が共崖化剤 として優れていることもピッチ共炭化の場合と共通し ている。崖化前に系外に放出される添加物でも，石炭 の炭化性に影響することができることは一見奇異であ るが，ピレンもしくはハイドロピレンが常压下で石炭 とかなりの収率でキノリン可溶に転換できる19)こと (いわゆる石炭液化反応) を併也て考光れば，これら 添加物の共存によって石炭が崖化前に改質され，炭化 性が向上することも可能であり，多くの SRC 沙炭 よりも大きな異方性組織を展開すること ${ }^{33}$ 亿対応して いると考光られる。

易黑鉛化性構造の生成は一般に異方性組織の展開々 は軌をひとつルしているので，上の議論を適応さ也る ことができよう。

本研究では異方性の展開の程度学顕微鏡の全視野定 観察する定性的判断に依拠したが，添加剤の效果を完
全に把握するためにはポイントカウンターを用いる定 量的判断が今後は必要であろう。

本砸究では粘着炭である三池炭を対象としたが，将 来，製鉄用コークス原料として，その利用が待望され るものは, 非粘着瀝青炭, 風化炭, 亜瀝青炭などの炭 化時に溶融しない岸種である。著者らは，これらの石 炭についても適当な添加剤との共炭化により異方性組 織の展開が可能であることを見出して和り ${ }^{34)}$ ，今後の 研究によって製鉄用コークス原料としての利用を期待 したい。

\section{文献}

1) R.R.Adair, E.H. Boult, and H.Marsh Fuel, 51, 57 (1972)

2）宮川覀夫，嵣䑾三男，谷原秀太郎，然協誌，56, 337 (1977)

3）杉村秀彦，熊谷光照，木村英雄，燃協誌，49, 744 (1970)

4) J.W. Patrick, M. J. Reynolds and F.H.Show, Fuel, 52, 198 (1973)

5) H. Marsh, Fuel, 52, 205 (1973)

6）熊井順二郎，山口 潔，丸山勝久，木村英雄，真 田雄三，燃協誌，55，164（1976）; 真田雄三，燃 協誌，57，3(1978)

7) A. Grint, U. Swietlik and H. Marsh, 5 th London Carbon and Graphite Conference, 226 (1978), London ; I. Mochida, K. Amamoto, K. Maeda, K. Takeshita, and H. Marsh, ibid.,237 (1978), London ; I. Mochida, H. Marsh and A. Grint, ibid., 245 (1978), London

8) I. Mochida, K. Kudo, K. Takeshita, R. Takahashi, Y. Suetsugu and J. Furumi, Fuel, 53, 253 （1974）；持田 勲, 泊康則, 岩永喜陽, 前田恵子, 竹下健次郎，然協誌，54，994（1975）

9) L. Reggel, R. Raymond, S. Friedman, R. A. Freidel, and I. Wender, Fuel, 37, 126 (1958)

10) B. Alpern, Brennstoff-Chemie, 37, 194 (1956)

11）杉村秀彦, 熊谷光照, 木村英雄, 燃協誌, 49,744 (1970)

12) J.W.Patrick, M.J. Reynolds, Carbon, 13, 509 (1975)

13）日本学術振興会第117委員会，炭菜，(36)，25 (1963)

14) F. Goodarzi and D.G.Murchison, Fuel, 57, 273 (1978)

15）持田 㹔，鍛治憲孝，葉山泰弘，前田恵子，竹下 
健次郎, 石油学会誌, 19, 750(1976)；I.Mochida, K. Maeda and K. Takeshita, Fuel Processing Technology, 1, 103 (1977/1978)

16) I. Mochida, K. Amamoto, K. Maeda and K. Takeshita, Fuel, 56, 49 (1977) ; 57, 225 （1978）; 持田 勲, 天本和馬, 前田恵子, 竹下健 次郎, 燃協誌, 56, 187 (1977) ; 石油学会誌, 20, 1025 (1977)

17) P. L. Walker, Jr. and A. Weinstein, Carbon, 5, 13 (1967)

18) H. Marsh, T. Dachille, J. Malvin and P. L. Walker, Carbon, 9, 159 (1971)

19）持田 勲, 財部明郎, 竹下健次郎, 燃協誌, 57, 729 (1978) ; I. Mochida, A. Takarabe, K. Takeshita, Fuel, in press. (1979)

20) I. Mochida, K. Kudo, N. Fukuda and K. Takeshita, Carbon, 13, 135 (1975)

I. Mochida, S. Inoue, T. Ando, K. Maeda and

K. Takeshita, Carbon, 15, 9 (1977)

21) J. D. Brooks and G.H. Taylor, "Chemistry and Physics of Carbon"(Edited by P.L. Walker, Jr.), Vol. 4, p. 243, Marcel Dekker, New York (1968)

22) E. Fitzer, K. Mueller and W.Schaefer,"Chemistry and Physics of Carbon",(Edited by P.L. Walker, Jr.), Vol. 7, p.237, Marcel Dekker, New York (1971)

23) H. Marsh, Symposium on Petroleum derived carbon, 20, 432 (1975)

24) J. L. White, ibid., 440 (1975)

25) I.Mochida, K.Maeda and K.Takeshita, Carbon, 15, 17 (1977)

26) J.M. Guet, F.Rousseaux and D.Tchoubar, 5 th London International Carbon and Graphite Conference, 296 (1978)

27) H. Honda, Y. Yamada, S. Oi and K. Fukuda, 11 th Conference on Carbon, Extended Abstract, American Carbon Society, 219 (1973)

28) K. J. Huttinger, Carbon, 1972 Barden-Barden, Abstract, 5, (1972)

29) C. A. Kovac and I. C. Lewis, 13 th Conference on Carbon, American Carbon Society, 199, (1977)

30) I. Mochida, H. Miyasaka, H. Fujitsu and K. Takeshita, Carbon, 15, 191 （1977）；持田勲, 宮坂仁一, 藤津 博, 竹下健次郎, 炭素, (92), 7, (1978)

31) I. Mochida, E. Nakamura, K. Maeda and K. Takeshita, Carbon, 13, 489 (1975) ; 14, 123 (1976)

32）持田 勲, 竹下健次郎, 石油学会誌, 20, 183 (1977)

33) M. Jeffery, H. Marsh, I.Mochida and E. Scott, 14 th Conference on Carbon (1979)

34) I. Mochida and H. Marsh, 14 th Conference on Carbon (1979) 


\title{
Modifying Optical Texture of the Coke from Miike Coal.
}

\author{
Isao Mochida, Seiji Moriyama, Hideichi Matsuoka, Keiko Maeda, \\ Hiroshi FujITsu, Kenjiro TAKEShita, ${ }^{*}$ and Harry MARSH** \\ (Industrial Science of Kyushu University* and University of Newcastle upon Tyne**)
}

\begin{abstract}
SINOPSIS :-Modifying optical texture of the coke from Miike coal of powdered form, which gave, singly carbonized, an isotropic coke, was investigated by applying the variable carbonization conditions, a carbonization catalyst and co-carbonization with some hydrocarbons and pitches. A rapid tempetature-rise was favourable to develop fine mosaic texture in a rather limited area of the coke. Aluminum chloride was effective to carbonize carbonecious materials, the degree of anisotropic development in the produced coke being influenced by the amount of the catalyst. Pyrene showed little modification ability as a co-carbonizing partner, whereas hydropyrene was a powerful agent to produce fine to coarse mosaic texture according to mixing ratio of 0.5 or 2.0 (mole ratio), respectively, although the former compound was not carbonized singly. Acenaphthylene and decacyclene which gave, singly carbonized, flow texture were also effective, the latter agent being quite powerful probably because of its high coke yield. Co-carbonization of hydrocarbons assisted by aluminum chloride could be effective to develop better anisotropy from fine to flow texture according to the amount of aluminum chloride and the hydrocarbons. Co-carbonization activities of several residual oils were also examined. Some of them are quite powerful to develop the flow texture by the mixing ratio of 1 to 2 . The development of anisotropic texture from the fusible coal is discussed from the viewpoint of carbonization mechanism where the mesophase formation is possibly influenced by the heating rate, the catalyst, and the co-carbonizing partners.
\end{abstract}

